\title{
COI-Based DNA Barcoding of Selais Fish from Arut River, Central Kalimantan, Indonesia
}

\author{
Tomi Kasayev ${ }^{1}$, Tuty Arisuryanti ${ }^{1 *}$ \\ 1)Laboratory of Genetics and Breeding, Faculty of Biology, Universitas Gadjah Mada, Jl. Teknika Selatan, Sekip Utara, Yogyakarta \\ 55281 \\ * Corresponding author, email: tuty-arisuryanti@ugm.ac.id
}

Keywords:

Selais Fish

Siluridae

DNA Barcoding

COI gene

Phylogenetics

Submitted:

10 June 2021

Accepted:

02 September 2021

Published:

26 January 2021

Editor:

Miftahul Ilmi

\begin{abstract}
Selais fish belongs to the family Siluridae consisting of 12 genera with 104 properly validated species. The human need for these fish has sharply increased due to the benefits provided, especially for consumption. However, morphologically the selais fish are slightly challenging to differentiate among other silurid fish for nonspecialist experts. Thus, a DNA barcoding approach using the mitochondrial COI gene as a molecular marker in this study was applied to clarify a taxonomic position and classification species of selais fish from Arut River (Central Kalimantan, Indonesia) and was also to assembly fish COI database storage from Indonesia. In this research, the method used was a PCR (Polymerase Chain Reaction) method with a pair of universal barcoding primers, FishF2 and FishR2. Based on partial COI fragment-based DNA barcoding, the whole samples showed no sequence differences (only 1 haplotype) within the population and this confirmed that these fish only consisted of one identical species. Furthermore, phylogenetic analysis (NJ / ML / BI) revealed that selais fish in this study had a close genetic relationship with Ompok hypophthalmus compared to other Ompok groups. This relationship was supported by the genetic distance value not exceeding 3.6\% and this evaluated the undetermined naming of the selais fish from Arut River which was previously still unclassifiable.
\end{abstract}

Copyright: C 2022, J. Tropical Biodiversity Biotechnology (CC BY-SA 4.0)

\section{INTRODUCTION}

Siluridae or commonly known as sheatfish is a part of the order Siluriformes consisting of 12 genera (Belodontichthys, Ceratoglanis, Hemisilurus, Kryptopterus, Micronema, Ompok, Phalacronotus, Pinniwallago, Pterocryptis, Silurichthys, Silurus, and Wallago) and 104 properly validated species (Fricke et al. 2021). In Indonesia, species members of the family Siluridae are commonly referred to as selais fish, such as Ompok bypophthalmus, Ompok myostoma, Kryptopterus apogon, Kryptopterus micronema, Kryptopterus limpok, and Kryptopterus bicirrbis (Jusmaldi et al. 2018). This is due to among selais fish almost possess similar morphological characters. In general, selais fish are characterized by a total length of about $30 \mathrm{~cm}$ to $45 \mathrm{~cm}$, a brightly colored body, and have maxillary and mandibular barbel (Kottelat 2013). Mostly, these fish inhabit rivers in the Sunda Shelf area such as Sumatra, Java, and Borneo (Ng 2003). Selais fish, for local communities, have mostly been being caught for consumption 
because they not only have a delicious taste but are also highly nutritious, so they can be used to meet animal protein needs.

Many research types on selais fish were carried out, but only a few studies at the molecular level. Arut River, one of the rivers in Central Kalimantan Province inhabited by selais fish, has become a concern area in this study. Overexploitation and overfishing have the potential to reduce the diversity and population number of selais fish. This is also supported by data at the IUCN which revealed there has been a decrease in the population for several species of selais fish. For conservation management efforts of Selais fish, especially in the Arut River, it is necessary to carry out initial data collection such as molecular identification of species names. Arisuryanti et al. (2020a) reported that the boundaries status and classification by identifying the selais fish using the $16 \mathrm{~S}$ mitochondrial gene were still undetermined due to low similarity and genetic distance values compared to the GenBank database. Although the COI mitochondrial gene is a high conserve region and highly acceptable for identification of almost all animals (Mitani et al. 2009), limited data in the GenBank database (unregistered) causes a low percentage of similarity and query cover for comparison, and this is a constraint in species determination.

Recently, a DNA barcoding approach using the mitochondrial COI gene as a molecular marker has been applied as a rapid alternative bioidentification method in clarifying taxa from the animal kingdom as a whole (Hebert et al. 2003), including ichthyofauna (Panprommin et al. 2019; Pandey et al. 2020). For example, Malakar et al. (2012) explained that three Ompok species from India were successfully identified as Ompok pabda, Ompokpabo, and Ompok bimaculatus. Arisuryanti et al. (2018) added that two cryptic fish species from Indonesia Periophthalmus argentilineatus and Periophthalmus kalolo were successfully confirmed. In addition, Chen et al. (2021), Chang et al. (2016), and Cline (2012) verified cases of mislabeling fish names from food products being sold.

Therefore, we tried to re-evaluate the uncertain taxonomic degree and systematic of selais fish from the Arut River using COI gene as taxonomic DNA by examining genetic relationships of three different phylogenetic tree approaches and this finding was also to compile the COI database library of the fish in Indonesia.

\section{MATERIALS AND METHODS}

\section{Sample Collection}

Wild selais fish with a total of 10 individuals from Arut River, Central Kalimantan $\left(2^{\circ} 40^{\prime} 10.6^{\prime \prime S}\right.$ and $\left.111^{\circ} 38^{\prime} 08.3^{\prime \prime E}\right)$ was collected (Figure 1) by asking local fisherman for help using large fishing nets and documented for this study (Figure 2). Approximately around $50 \mathrm{mg}$ muscle tissue of these freshly caught fish was sampled and placed into $1.5 \mathrm{ml}$ labelled tubes containing $99 \%$ absolute ethanol. The samples were transferred and then frozen at a 


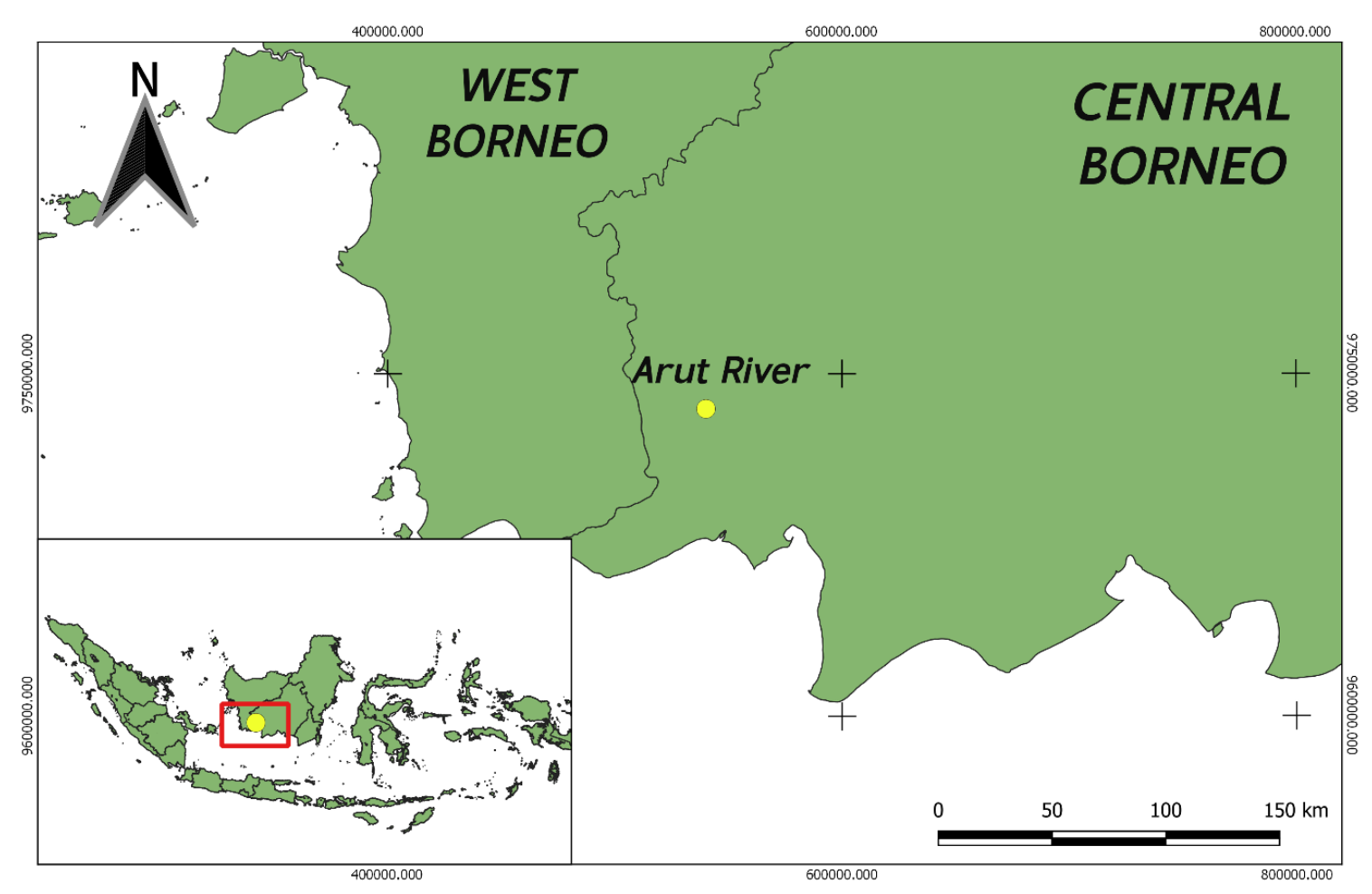

Figure 1. Yellow spot showed sampling area in Arut River, Central Kalimantan. Inset: Indonesian map.

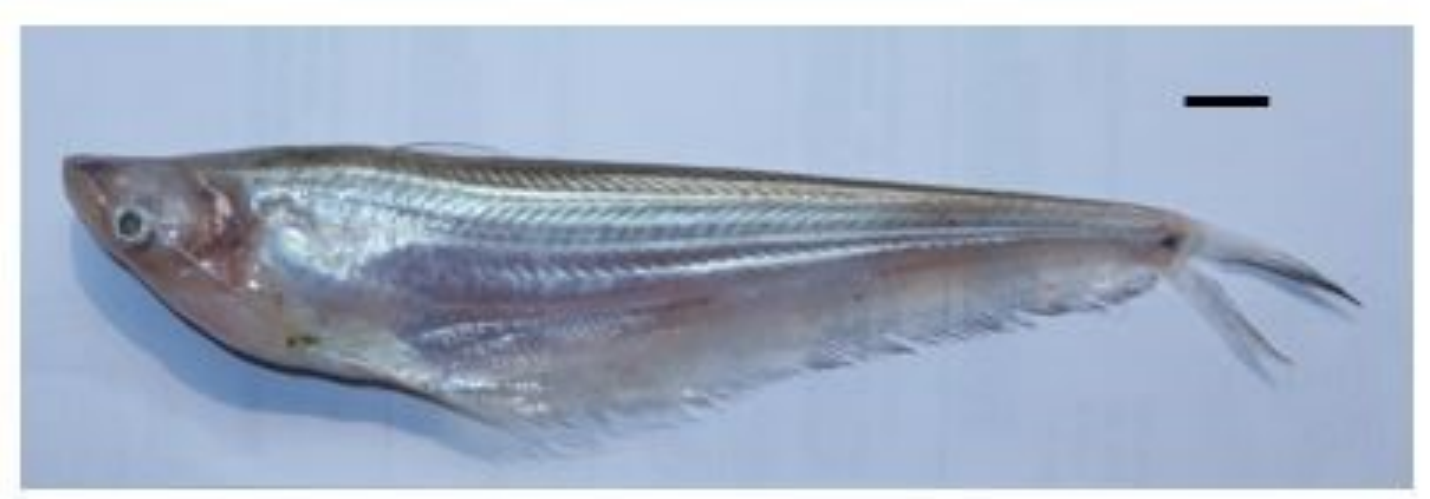

Figure 2. Selais fish documented from Arut River, Central Kalimantan (bar $=1 \mathrm{~cm})$.

temperature of $-20^{\circ} \mathrm{C}$ in the Laboratory of Genetics and Breeding, Faculty of Biology, Universitas Gadjah Mada, for further molecular analysis.

\section{DNA Isolation, Amplification, and Sequencing}

The complete genomic DNA (gDNA) of preserved samples was isolated from the muscle tissue (cells) near the ventral fin using the DNeasy Blood and Tissue Kit (QIAGEN, Valencia, USA) following the factory's protocol. The single COI fragment was amplified using a PCR machine with barcode primer FishF2 and FishR2 (5'-TCGACTAATCATAAA GATATCGGCAC3' and 5'-ACTTCAGGGTGACCGAAGAATCAGAA-3') respectively (Ward et al. 2005). Of $50 \mu$ l total volume of PCR reaction, 10-100 ng was gDNA, $25 \mu \mathrm{l}$ was My Taq HS Red Mix PCR (bioline), $2 \mathrm{mM}$ was $\mathrm{MgCl}_{2}, 3 \mu \mathrm{l}$ was the two sets of COI primer, and $11 \mu \mathrm{l}$ was $\mathrm{ddH}_{2} \mathrm{O}$. The PCR machine was conditioned at $95^{\circ} \mathrm{C}$ in $1 \mathrm{~min}$ for pre-denaturation followed by 35 repeated cycles for denaturation at $95^{\circ} \mathrm{C}$ in $15 \mathrm{sec}$, primer annealing at $50^{\circ} \mathrm{C}$ in 
$30 \mathrm{sec}$, elongation at $72^{\circ} \mathrm{C}$ in $30 \mathrm{sec}$, and at $72^{\circ} \mathrm{C}$ for $1 \mathrm{~min}$ for final elongation and ended by the hold at $4{ }^{\circ} \mathrm{C}$.

The PCR product was visualized using $2 \mu \mathrm{l}$ staining FloroSafe in 1\% agarose gel. The amplicon was then purified and sequenced at 1st BASE company using a pair of the same universal primers during amplification process. Bi-directional COI gene sequencing with sanger dideoxynucleotide sequencing method was performed using the ABI 3730XL Genetic Analyzer machine (Applied Biosystems).

\section{Data Analysis}

Sequence data set were processed and set manually using the SeqMan and EditSeq programs (Lasergene, DNASTAR). The appropriate consensus sequence was analyzed using the Identification Engine program in the BOLD website and the BLAST program in the NCBI website to determine percentage identity. For either intra-population (population of selais fish from Arut River in this study) or intra-species analysis (sample combination between this study and GenBank database), sequence data were further aligned in MESQUITE ver. 3.51 (Maddison \& Maddison 2018). The nucleotide composition and genetic distance with the Kimura 2-Parameter (K2P) substitution model were then analyzed in MEGA X (Kumar et al. 2018). Next, data of genetic variations (number of haplotypes, polymorphic sites, parsimony sites, transition and transversion, haplotype diversity, and nucleotide diversity) was processed in DnaSP ver. 6 (Rozas et al. 2017). The haplotype network based on the Median Joining Network method was visualized in NETWORK ver. 10.1 (https://www.fluxus-engineering.com). Furthermore, Principal Coordinate Analysis (PCA) was analyzed in GenAlEx ver. 6.5 (Peakall $\&$ Smouse 2012) to obtain a simple separation model among haplotypes.

The phylogenetic tree character was defined using three different approaches. The NJ (Neighbor-Joining) and ML (Maximum Likelihood) trees were characterized using the Kimura 2-Parameter (K2P) model with 1,000 bootstrap replications in MEGA X. Bayesian Inference (BI) tree topology was analyzed using the Bayesian Information Criterion (BIC) approach in the jModelTest ver 2.1.10 program (Darriba et al. 2012) to select the most suitable nucleotide substitution model. Furthermore, the BI tree was analyzed in BEAST ver. 1.10 program under the best appropriate model (Suchard et al. 2018). The MCMC (Markov Chain Monte Carlo) analysis was run $10^{7}$ with $10^{3}$ samples per generation. The first quarter of files were removed (burn-in), other three-quarter files were performed to construct the BI tree and measure posterior probability value. Phylogeny tree characteristics were visualized in Figtree v.1.4.4 (Rambaut 2019). Node on each branch represented the bootstrap (NJ/ML)/posterior probability (BI) value. Thirteen Ompok spp. consisting of 6 species were taken from GenBank for comparison purposes, namely Ompok bypophthalmus (MK473377 - MK473379), Ompok engeneiatus (MK473374 and MK473376), Ompok bimaculatus (JX983415, JX983418, and JX260925), Ompok pabo (KX946739 and JN628926), Ompok malabaricus 
(HQ009495), Ompok pabda (JX260929 and JX260930), and Anabas testudineus (MN640070) is used for the outgroup.

\section{RESULTS AND DISCUSSION}

Nine out of all selais fish samples from Arut River were successfully amplified and sequenced using Fish F2 and Fish R2 primers (codes: LSA-1, LSA-2, LSA-5, LSA-6, LSA-7, LSA-8, LSA -9, LSA-10, LSA-11) and produce about 678-705 bp (226-235 amino acids). The one remaining sample yielded a poor sequence even though the DNA band was visible (Code: LSA-4) (Figure 3). The nine COI sequence data of selais fish have been registered in GenBank with accession number MZ634366-MZ634374.

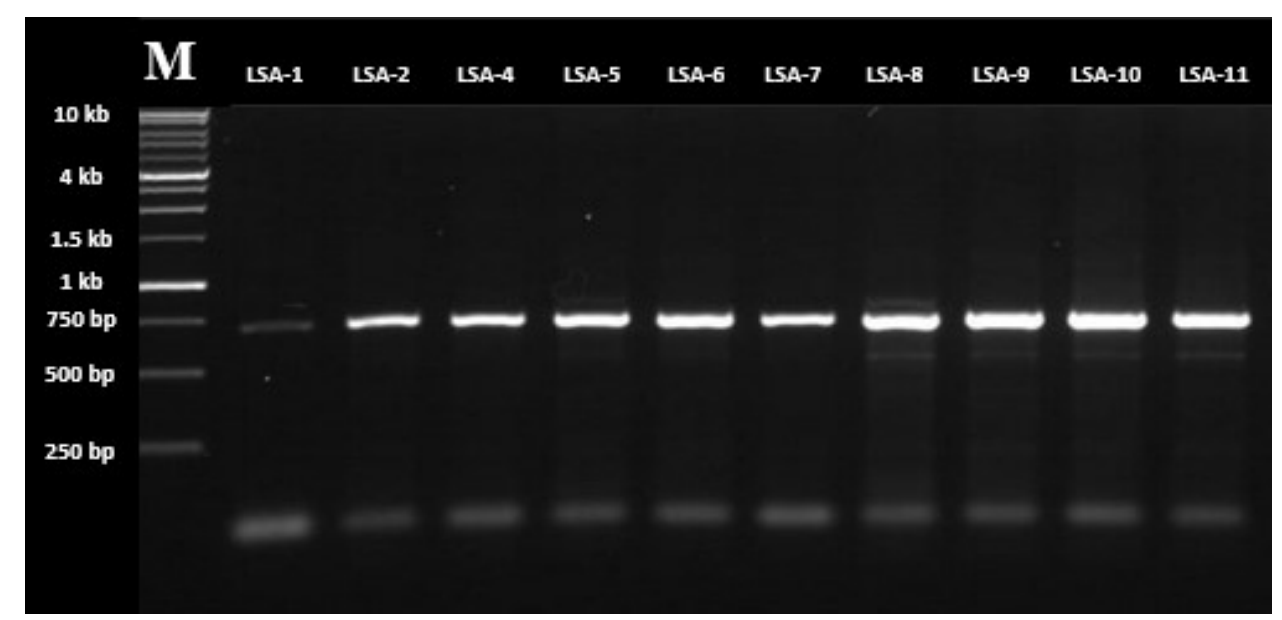

Figure 3. The result of COI mitochondrial gene amplification was visualized on the electropherogram. LSA was selais fish sample code and M was a marker.

The Identification Engine algorithm in BOLD and the BLAST algorithm in GenBank showed that these samples had percentage identity with Ompok bypopthalmus of $96.71 \%$ - 97.19\% (BOLD) and 96.61\% - 96.77\% (GenBank). In particular, the COI gene sequence data of Ompok hypophthalmus in BOLD with a similarity value of $97.19 \%$ was still private data. This indicates that the COI gene sequence data has not been released to the public. Therefore, for comparison data, only the released COI sequence of Ompok bypophthalmus was analyzed. For intra-population level analysis, the COI gene sequences were aligned and resulted in 672bp (224 amino acids).

The mean nucleotide composition obtained was $\mathrm{C}=30.65 \%$, $\mathrm{T}=$ $26.64 \%, A=24.40 \%$, and $G=18.30 \%$ with a slightly higher amount of AT than the total CG. The CG content values not exceeding 50\% were also detected in 6 species from 2 genera consisted of Ompok pabda (49.3\%), Ompok pabo (46.4\%), and Ompok bimaculatus (45.6\%) (Malakar et al. 2012), Kryptopterus apogon (46.40\%), Kryptopterus micronema (46.40\%), and Kryptopterus limpok (46.40\%) (Jusmaldi et al. 2017). This total can also be found for several marine fish species (Xu et al. 2021) and freshwater fish species (Arisuryanti et al. 2020b; Pandey et al. 2020). All samples showed identical sequences (only one haplotype) indicating no sequence variation within a population. 
The three statistical methods of the phylogenetic tree formed almost similar tree topology, and the tree was only displayed using the NJ approach (Figure 4). For BI tree was constructed using the HKY (Hasegawa KishinoYano) with the gamma-distributed rate $(+\mathrm{G})$ and invariant site $(+\mathrm{I})$ as an ideal reference for substitution model under BIC in jModelTest. All samples from Arut River were grouped of only a clade (clade A) with a very strong bootstrap of 100/100 (for both NJ and ML) and posterior probability value of 1 (for BI). This indicates that the entire fish sample consisted of only one species, which was supported by $0 \%$ genetic distance among samples. This was confirmed by Roesma et al. (2020) that species possessing a genetic distance from $0 \%$ to $0.5 \%$ were still indicated as one identical species.

Furthermore, the samples (LSA) had a closer genetic relationship with Ompok hypophthalmus (MK473377, MK473378, and MK473379) in clade B compared to other Ompok groups. This was confirmed by quite a significant bootstrap value (100/98) and posterior probability (1) and the mean of genetic distance between clade A dan clade B was 3.6\%. A previous study by Arisuryanti et al. (2020a) described that selais fish based on the $16 \mathrm{~S}$ mitochondrial gene were closer to genus Kryptopterus than genus Ompok with significant differences in genetic distance of $44.1 \%$ and $65.8 \%$, respectively. This discovery has confirmed that the ambiguous name and dispels doubts of selais fish previously were still unclassified accurately.

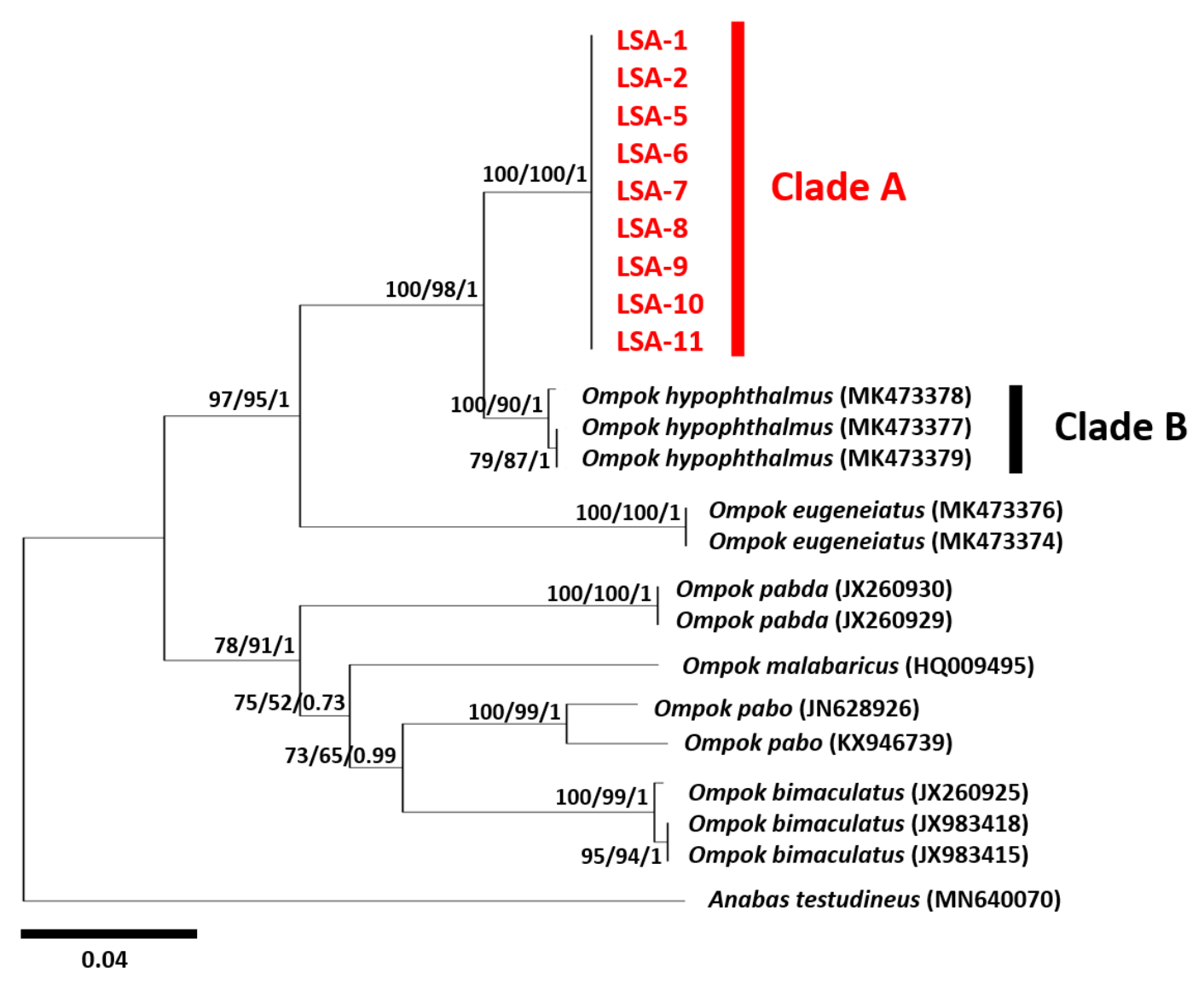

Figure 4. Phylogenetic tree reconstruction using three different statistics (NJ / ML / BI) based on COI mitochondrial gene. The tree was only displayed in the NJ approach. The number on nodes represented bootstrap (NJ/ML)/ posterior probability (BI). 
For more detail, the intra-species analysis between selais fish and Ompok bypophthalmus (MK473377, MK473378, and MK473379) resulted in 633 bp-alignment sequences. Each nucleotide composition was presented in Table 1. There were no significant divergences in nucleotide composition between LSA* and Ompok bypophthalmus from the GenBank database. Total composition divergence of nucleotide LSA* was relatively similar from the 12 individuals with $\mathrm{T}=0 \%-0.47 \%, \mathrm{C}=0 \%-0.63 \%, \mathrm{~A}=0 \%-0.32 \%$, and $\mathrm{G}=$ $0 \%-0.47 \%$. The AT composition for all samples was greater than the CG content but with the same difference of $0.79 \%$.

The genetic distance for each sample was expressed in Table 2. The intra-species genetic distance ranged from $0 \%$ to 3.6\%. The highest value was obtained between LSA* and MK473377, MK473378, and MK473379. The lowest percentage of genetic distance was between MK473377 and MK473379. Zemlak et al. (2009) stated that the species was still categorized as one species if the intra-species genetic distance threshold value was 3.5\%. Meanwhile, the genetic distance between selais fish in this study and Ompok bypophthalmus from Indragiri River, Riau was 3.6\%. However, samples in this study were still classified as Ompok hypophthalmus due to high similarity from BOLD database $97.19 \%$, which means the genetic distance was still $<3.5 \%$. However, the mitochondrial COI gene sequence has been in private data, which means that the COI sequence of Ompok hypophthalmus has been registered in BOLD but has not been released to the public (Table 4). Haplotype grouping between selais fish from Arut River and Ompok bypophthalmus from GenBank database was presented in Table 3.

Table 1. Percentage of nucleotide composition (\%) based on COI mitochondrial gene between selais fish and Ompok, bypophthalmus from GenBank database (COI fragment length = 633 bp).

\begin{tabular}{ccccccc}
\hline Accession Number & $\mathrm{T}(\mathrm{U})$ & $\mathrm{C}$ & $\mathrm{A}$ & $\mathrm{G}$ & $\mathrm{A}+\mathrm{T}$ & $\mathrm{C}+\mathrm{G}$ \\
\hline LSA $^{*}$ & 26,57 & 30,66 & 24,69 & 18,08 & 51,26 & 41,08 \\
MK473377 & 26.10 & 31,29 & 24,37 & 18,24 & 50,47 & 49,53 \\
MK473378 & 26.10 & 31,29 & 24,37 & 18,24 & 50,47 & 49,53 \\
MK473379 & 26.10 & 31,29 & 24,37 & 18,24 & 50,47 & 49,53 \\
\hline
\end{tabular}

*Mean

Table 2. Percentage of intra-species genetic distance (\%) based on COI mitochondrial gene between Selais fish and Ompok hypophthalmus from GenBank database.

\begin{tabular}{ccccc}
\hline Accession Number & LSA* & MK473377 & MK473378 & MK473379 \\
\hline LSA* & & & & \\
MK473377 & 3.6 & & \\
MK473378 & 3.6 & 0.3 & \\
MK473379 & 3.6 & 0 & 0.3 & \\
\hline
\end{tabular}


Table 3. Haplotype grouping based on COI mitochondrial gene.

\begin{tabular}{|c|c|c|c|c|}
\hline Clade & Haplotype & $\begin{array}{l}\text { Total } \\
\text { individuals }\end{array}$ & Sample Code & Location \\
\hline \multirow[t]{10}{*}{$\overline{\mathrm{A}}$} & HapA & 9 & LSA-1 & This Study \\
\hline & & & LSA-2 & This Study \\
\hline & & & LSA-5 & This Study \\
\hline & & & LSA-6 & This Study \\
\hline & & & LSA-7 & This Study \\
\hline & & & LSA-8 & This Study \\
\hline & & & LSA-9 & This Study \\
\hline & & & LSA-10 & This Study \\
\hline & & & LSA-11 & This Study \\
\hline & HapB1 & 2 & $\mathrm{MK} 473377$ & Indragiri River \\
\hline \multirow[t]{2}{*}{ B } & & & MK473379 & Indragiri River \\
\hline & HapB2 & 1 & MK473378 & Indragiri River \\
\hline
\end{tabular}

The intra-species polymorphism sites among haplotypes were shown in Table 4. Of three haplotypes, there were 23 variable nucleotide sites $(3.61 \%)$ with 22 informative parsimony sites $(3.46 \%)$ and a singleton site $(0.16 \%)$. Nucleotide diversity $(\pi)$ and haplotype diversity $(\mathrm{Hd})$ were $0.0142 \pm 0.00468$ and $0.439 \pm 0.158$ ( $\mathrm{Hd}$ value $0<0.5$ low haplotype diversity and $\mathrm{Hd}>0.5 \leq 1$ high haplotype diversity), consecutively. This indicates $\pi$ and Hd were low indexes. It is assumed that the samples in this study have a small population. The nucleotide divergence models in this sequence were fully substitutions with 22 sites $(3.46 \%)$ represented transition and transversion was only one site $(0.16 \%)$. Almost all base divergences were in the third position (20 sites / $3.14 \%$ ), followed by the first codon position ( 3 sites / $0.47 \%$ ), and no nucleotide divergences in the second codon position (0 sites / $0 \%)$. In addition, one nonsynonymous (from isoleucine to valine) was detected in the 145 th codon.

The inter-haplotype mutation model was designed in Figure 5. Based on Figure 5, a very clear separation was depicted between haplotype A (HapA) and haplotype $B\left(\mathrm{HapB}_{1}\right.$ and $\left.\mathrm{HapB}_{2}\right)$ due to many substitutions of the nucleotide arrangement. Between HapA and $\mathrm{HapB}_{1}$ also HapA and Hap$\mathrm{B}_{2}$, there were 22point mutations. Intra-haplogroup $\mathrm{B}\left(\mathrm{HapB}_{1}\right.$ and $\left.\mathrm{HapB}_{2}\right)$ was inserted with only 2 mutation points. In general, the presence of intra-

Table 4. Intra-species polymorphism sites based on COI mitochondrial gene among haplotypes.

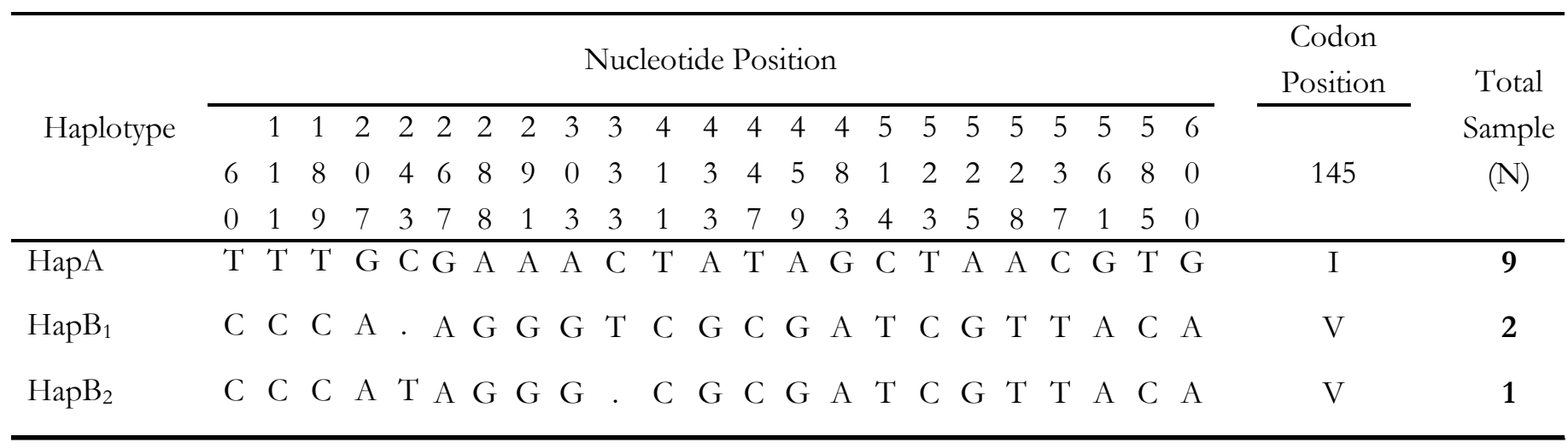


species genetic variation between selais fish from Arut River and Ompok bypophthalmus (3 haplotypes) was simplified in the Principal Coordinate Analysis (PCA) pattern in Figure 6.

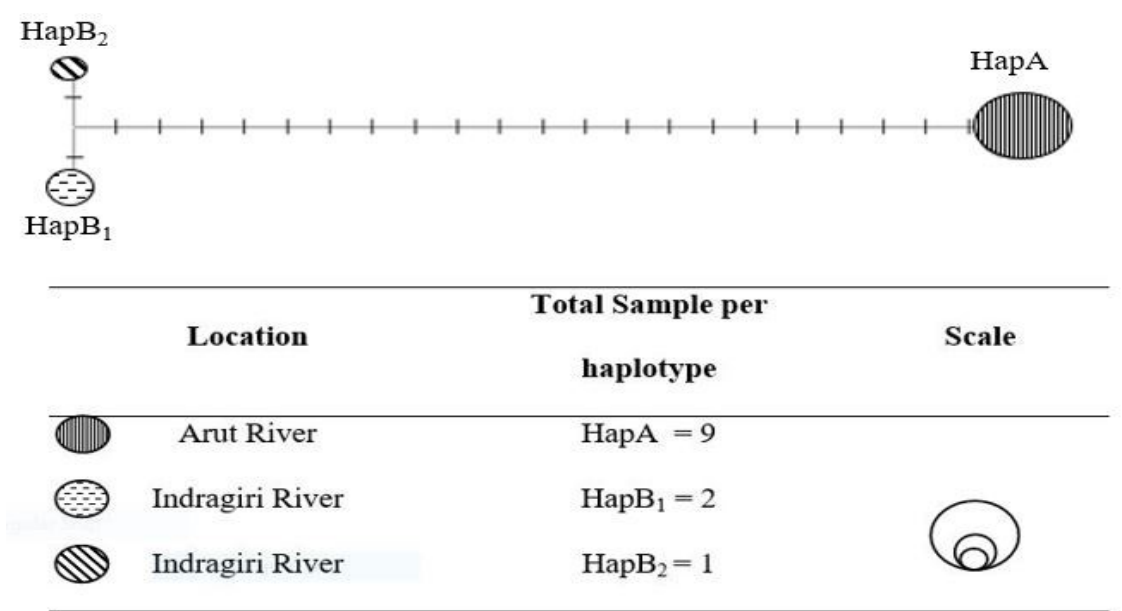

Figure 5. Median joining-haplotype network based on COI mitochondrial gene among haplotypes.

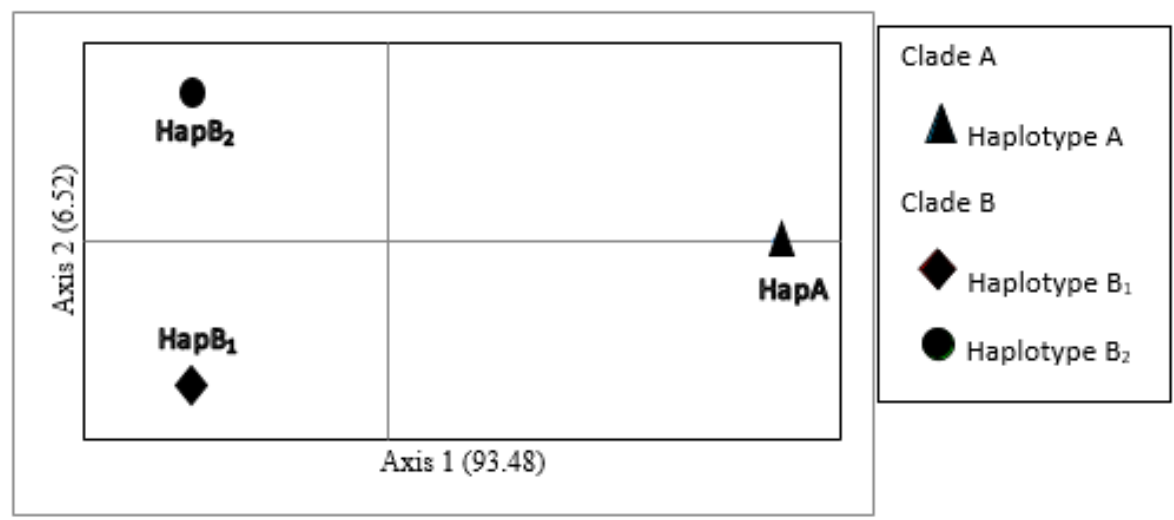

Figure 6. Principal Coordinates Analysis (PCA) based on COI mitochondrial gene among haplotypes.

\section{CONCLUSION}

By way of conclusion, DNA barcoding using the partial COI mitochondrial gene was quite effective and acceptable for molecular identification, especially for morphologically indistinguishable species. Based on the phylogenetic tree construction $(\mathrm{NJ} / \mathrm{ML} / \mathrm{BI})$, selais fish from Arut River had been confirmed as one single taxa Ompok hypophthalmus supported by a genetic distance value of $3.6 \%$. The results of this study are also expected to be used as an entry point for the formulation of sustainable fisheries management and conservation strategies considering that the enormous potential of this important fish can provide maximum benefits in a sustainable manner if managed properly and responsibly.

\section{AUTHORS CONTRIBUTION}

T.K. collected and analyzed the data and wrote the manuscript. T.A. designed the research and supervised all the processes. 


\section{ACKNOWLEDGMENTS}

We profoundly thanked the Head of the Laboratory of Genetics and Breeding, Faculty of Biology, Universitas Gadjah Mada who gave permission and facilitated for research. We also sincerely thanked to Field and Laboratory Work Team who had contributed during this study. This research has been supported by RTA-UGM 2020 funding with contract No. 2488/UN1.P.III/ DIT-LIT/PT/2020

\section{CONFLICT OF INTEREST}

The authors state that there is no conflict of interest. They were fully responsible for the writing of the manuscript.

\section{REFERENCES}

Arisuryanti et al., 2018. Genetic identification of two mudskipper species (Pisces: Gobiidae) from Bogowonto Lagoon (Yogyakarta, Indonesia) using COI mitochondrial gene as a DNA barcoding marker. AIP Conference Proceedings, 2002. doi: 10.1063/1.5050164.

Arisuryanti et al., 2020a. Determination of species boundaries of Selais fish from Arut River, Central Kalimantan based on 165 mitochondrial gene using Bayesian approach. BIO Web of Conferences, 28. doi: 10.1051/ bioconf/20202801003.

Arisuryanti et al., 2020b. Composition of mitochondrial DNA COI nucleotide of striped snakehead (Channa striata Bloch, 1793) collected from three rivers in Sumatra and Kalimantan. AIP Conference Proceedings, 2260. doi: $10.1063 / 5.0015907$

Chang, C.H. et al, 2016. DNA barcode identification of fish products in Taiwan: Government-commissioned authentication cases. Food Control, 66, pp. 38-43. doi: 10.1016/j.foodcont.2016.01.034.

Chen, C. et al., 2021. DNA barcoding of yellow croakers (Larimichthys spp.) and morphologically similar fish species for authentication. Food Control, 127(4), p.108087. doi: 10.1016/j.foodcont.2021.108087

Cline, E., 2012. Marketplace substitution of Atlantic salmon for Pacific salmon in Washington State detected by DNA barcoding. Food Research International, 45(1), pp.388-393. doi: 10.1016/j.foodres.2011.10.043

Darriba, D. et al., 2012. jModelTest 2: more models, new heuristics and parallel computing. Nature Methods, 9(8), pp.772-772. doi: 10.1038/ nmeth.2106

Fricke, R., Eschmeyer, W. N. \& Fong, J. D., 2021. 'Eschmeyer's Catalog of Fishes: Genera/Species By Family/Subfamily', viewed 10 May 2021, from http://researcharchive.calacademy.org/research/ichthyology/ catalog/SpeciesByFamily.ap

Hebert, P.D. et al., 2003. Biological identifications through DNA barcodes. Proceedings of the Royal Society of London. Series B: Biological Sciences, 270(1512), pp.313-321. doi: 10.1098/rspb.2002.2218 
Jusmaldi, N.F.N. et al., 2017. Kode batang DNA ikan lais genus Kryptopterus asal Sungai Mahakam, Kalimantan Timur [Barcoding DNA of catfish species genus Kryptopterus from Mahakam River, East Kalimantan]. Jurnal Iktiologi Indonesia, 14(3), pp.191-199. doi: 10.32491/ jii.v14i3.80.

Jusmaldi, J. et al., 2018. Sebaran dan kekayaan spesies ikan lais (famili Siluridae) di Sungai Mahakam Kalimantan Timur [Distribution and species diversity of lais fish (family Siluridae) from Mahakam River, East Kalimantan]. Proceeding of Biology Education, 2(1), pp.18-25.

Kottelat, M., 2013. The fishes of the inland waters of Southeast Asia: a catalogue and core bibliography of the fishes known to occur in freshwaters, mangroves and estuaries. Raffles Bulletin of Zoology, 27, pp. 1-663

Kumar, S. et al., 2018. MEGA X: molecular evolutionary genetics analysis across computing platforms. Molecular Biology and Evolution, 35(6), p.1547-1549. doi:10.1093/molbev/msy096

Maddison, W. P. \& Maddison, D.R., 2018, 'Mesquite: a modular system for evolutionary analysis version 3.61', viewed 10 February 2021, from http://www.mesquiteproject.org

Malakar, A.K. et al., 2012. Molecular identification of three Ompok species using mitochondrial COI gene. Mitochondrial DNA, 23(1), pp.20-24. doi: 10.3109/19401736.2011.643876

Mitani, T. et al., 2009. Identification of animal species using the partial sequences in the mitochondrial 16S rRNA gene. Legal Medicine, 11, pp. S449-S450. doi: 10.1016/j.legalmed.2009.02.002.

$\mathrm{Ng}, \mathrm{H} . \mathrm{H} ., 2$ 2003. A review of the Ompok hypophthalmus group of silurid catfishes with the description of a new species from South-East Asia. Journal of Fish Biology, 62(6), pp.1296-1311. doi:10.1046/j.10958649.2003.00107

Pandey, P.K. et al., 2020. DNA barcoding and phylogenetics of freshwater fish fauna of Ranganadi River, Arunachal Pradesh. Gene, 754, p.144860. doi: 10.1016/j.gene.2020.144860.

Panprommin, D. et al., 2019. DNA barcodes for the identification of species diversity in fish from Kwan Phayao, Thailand. Journal of Asia-Pacific Biodiversity, 12(3), pp.382-389. doi: 10.1016/j.japb.2019.05.003.

Peakall, R. \& Smouse, P.E., 2012, GenAlEx 6.5: genetic analysis in Excel. Population genetic software for teaching and research-an update. Bioinformatics, 28(19), pp. 2537-2539. doi:10.1093/bioinformatics/bts460.

Rambaut, A., 2019, 'FigTree v 1.4.4.' viewed 10 February 2021, from http:// tree.bio.ed.ac.uk/software/figtree/

Roesma, D.I., Tjong, D.H. \& Aidil, D.R., 2020. Phylogenetic analysis of transparent gobies in three Sumatran lakes, inferred from mitochondrial Cytochrome Oxidase I (COI) gene. Biodiversitas Journal of Biological Diversity, 21(1), pp.43-48. doi: 10.13057/biodiv/d210107. 
Rozas, J. et al., 2017. DnaSP 6: DNA sequence polymorphism analysis of large data sets. Molecular Biology and Evolution, 34(12), pp.3299-3302. doi:10.1093/molbev/msx248.

Suchard, M.A. et al., 2018. Bayesian phylogenetic and phylodynamic data integration using BEAST 1.10. Virus Evolution, 4(1), p.vey016. doi: $10.1093 /$ ve/vey016.

Ward, R.D. et al., 2005. DNA barcoding Australia's fish species. Philosophical Transactions of the Royal Society B: Biological Sciences, 360(1462), pp.18471857. doi: 10.1098/rstb.2005.1716.

$\mathrm{Xu}, \mathrm{L}$. et al., 2021. Assessment of fish diversity in the South China Sea using DNA taxonomy. Fisheries Research, 233, p.105771. doi: 10.1016/ j.fishres.2020.105771.

Zemlak, T.S. et al., 2009. DNA barcoding reveals overlooked marine fishes. Molecular Ecology Resources, 9, pp.237-242. doi: 10.1111/j.17550998.2009.02649.x. 